\title{
Atipik İnflamatuar Bel Ağrısı
}

İbrahim TEKEOĞLU1 ${ }^{1}$, Ayhan KAMANLI ${ }^{1}$, Gökhan KOZ ${ }^{1}$

47 yaşında bir erkekte 2 yıldan beri boyun ve sırt ağrısı vardı ancak bu ağrı son iki haftadır lomber ve kalça bölgelerinde belirgin artış gösterdi. Son birkaç haftadır bel ve kalça bölgesi ağrısından yakınan hastada ne olabilir?

Gönderi Tarihi:01.12.2017

Anahtar Kelimeler: İnflamatuar bel ağrısı, bel, kalça
Kabul Tarihi:06.12.2017

Online Yayın Tarihi:31.12.2017

DOI: $10.26453 /$ otjhs.360004

Sorumlu Yazar

İbrahim TEKEOĞLU

\section{Atypical Inflammatory Back Pain}

İbrahim TEKEOĞLU1 ${ }^{1}$, Ayhan KAMANLI ${ }^{1}$, Gökhan KOZ ${ }^{1}$

\begin{tabular}{|c|c|}
\hline Abstract & Article Info \\
\hline $\begin{array}{l}\text { A } 47 \text { year old male has been complained for cervical and dorsal pain for two years but the pain } \\
\text { was significantly apparent in lumbar and hip area in last few weeks. What could be the cause }\end{array}$ & Received:01.12.2017 \\
\hline of pain at lumbar and hip areas in the last a couple of weeks? & Accepted:06.12.2017 \\
\hline \multirow[t]{4}{*}{ Keywords: Inflammatory back pain, lumbar, hip } & Online Published:31.12.2017 \\
\hline & DOI: $10.26453 /$ otjhs.360004 \\
\hline & Corresponding Author \\
\hline & İbrahim TEKEOĞLU \\
\hline
\end{tabular}

${ }^{1}$ Sakarya Üniversitesi Tıp Fakültesi, Fizik Tedavi ve Rehabilitasyon A.D. SEAH FTR-Romatoloji Kliniği. 


\section{GíRiș}

Soru: 47 yaşında, erkek, 2 yıl önce servikal bölgede başlayan ağrı ve tutukluk şikayeti olan hasta için olası tanınız nedir? (Resim 1) ve (Resim-2 A-B)

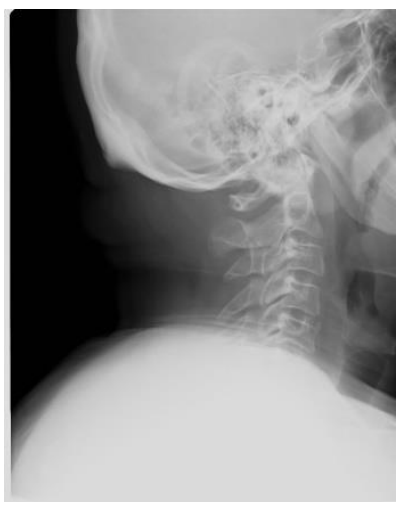

Resim 1. Servikal lateral grafi.
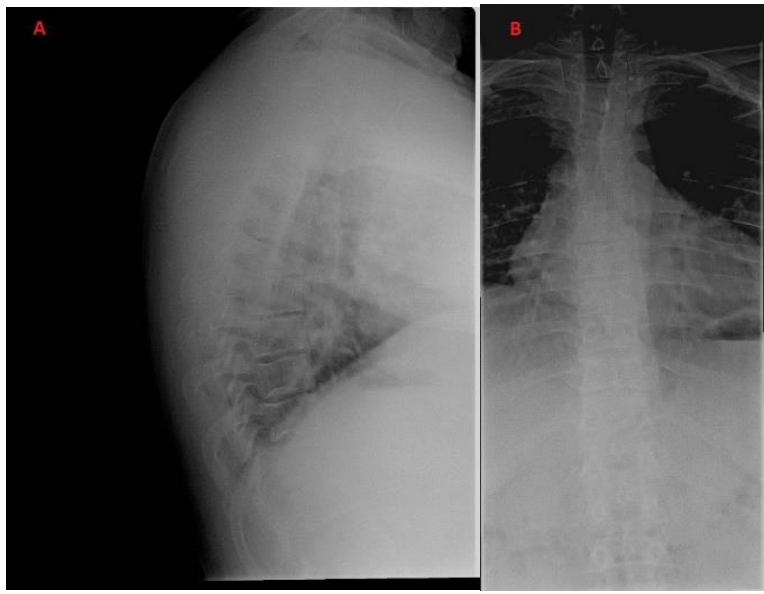

Resim 2. Dorsal lateral (A) ve AP (B) grafiler

Hasta son birkaç haftadır bel ve kalça bölgesi ağrısından yakınmaktadır. 2 yıl önce geçirdiği pnömoni sonrasında başlayan boyun bölgesinde ağrı ve tutukluk şikayeti mevcuttu. Gece sabaha doğru uykudan uyandıran dorsal-servikal ağrı ve sabah 2-3 saat süren tutukluk tarifliyordu. Hasta son birkaç haftadır ağrılarının bel ve kalça bölgesinde de başladığını belirtiyordu. Hastadan suprapubik grafi ve MRI görüntüleme istendi.(Resim-3 C-D) Olası tanınız nedir?

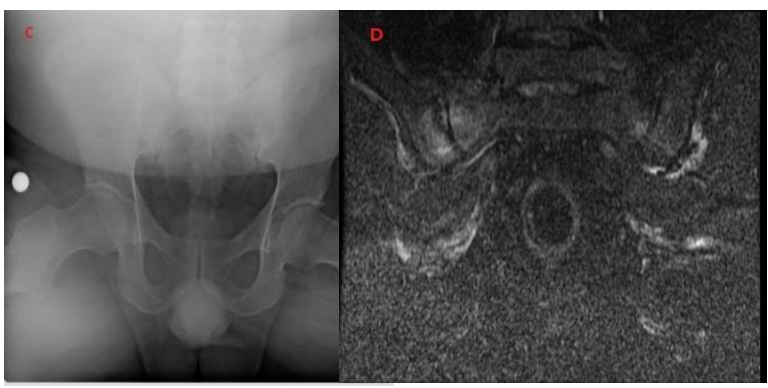

Resim 3. Suprapubik pozisyonda sakroiliak grafi (C) ve MRI (D) görüntüleri

Hastanın romatolojik sorgusunda oral ve genital aft/ülser, üveit öyküsü, ailede romatolojik hastalık öyküsü, psöriasis, Raynaud fenomeni, eritema nodozum, dispne, ağız ve göz kuruluğu, artrit ve artralji öyküsü, karın ve göğüs ağrısı atakları, fotosensitivite, s1k tekrarlayan ishal, kabızlık veya üriner enfeksiyon, geçirilmiş derin ven trombozu öyküsü yoktu. Sadece inflamatuar tarzda aksiyal ağrı tarifliyordu. Hastada periferal artrit, entezit veya daktilit bulgusu yoktu. Hasta 2 yıl öncesinde servikodorsal bölgedeki ağrı tutukluk nedeniyle romatoloji polikliniğine başvurmuş. Yapılan incelemelerde miyofasiyal ağrı sendromu tanısı alan hasta nonsteroidal anti inflamatuar ilaçlar, miyoreleksan grubu ilaçlar, duloksetin ve pregabalin tedavisi almıș. Verilen tedaviden fayda görmeyen hasta ilaçları bırakmış. Hastanın yapılan fizik muayenesinde servikal eklem hareket açıklığı (EHA) fleksiyon ve ekstansiyon 40 derece, lateral fleksiyonlar bilateral 15 derece, rotasyonlar ise 45 derece kadar yapabiliyordu. Her iki omuz EHA ağrısız ve tamdi. Lomber fleksiyon 60 derece, ekstansiyon 25 derece, lateral fleksiyonlar 20 
derece, rotasyonlar 15 derece olarak ölçüldü. Elparmak-zemin mesafesi $10 \mathrm{~cm}$, çene sternum mesafesi $2 \mathrm{~cm}$ olarak ölçüldü. Lateral fleksiyonlar sonrası parmak-zemin mesafesinde $7 \mathrm{~cm}$ fark vard1. Lomber shober fark1 $6 \mathrm{~cm}$ 'di. Göğüs ekspansiyonu $2 \mathrm{~cm}$ olarak ölçüldü. Hastanın laboratuvar bulgularında beyaz küre (WBC):9.300, hemoglobin:13.3 mg/dl, hematokrit:39.9, platelet:306000, nötrofil:5290, lenfosit:3240, monosit:523, eozinofil:191, bozofil:56, ürik asit:5,4, kreatinin:0.64, üre: 29 , AKŞ:370, ALT:22, AST:23, GGT:33, alkalen fosfataz:107, total protein:8.2, albümin:3.8, globülin:4.4, sodyum:132, potasyum:4,8, klor:95, kalsiyum:9.5, fosfor:3.1, LDH:177, Eritrosit Sedimentasyon Hizı (1 saat):52, CRP:17,6, RF: <11,5, CCP:negatif ( - ) , ASO:384, idrar tetkikinde: glukoz ++ görülürke, keton, protein, eritrosit, lökosit negatif görülmüştür. Hastanın genetik analizinde HLAB27 negatif olarak sonuçland1. Suprapubik pozisyonda çekilen sakroiliak grafide sakroiliitle ilgili bulgu saptanmadı. (Resim-3-C) Fakat çekilen sakroiliak MRI 'da bilateral sakroiliit ile uyumlu kemik iliği ödemi saptandı(Resim-3-D). Hastaya inflamatuar aksiyal ağrı ile beraber nonradiyografik aksiyal SpA tanısı kondu ve indometazin ile salazopyrin tedavisi başlandı. Hasta verilen NSAIII ve salazopyrin ile ağrılarının ve sabah tutukluğunun azaldığını belirtti.

\section{TARTIŞMA}

İnflamatuar bel ağrısı spondilartropatilerin tipik ilk klinik bulgusu olarak değerlendirilmektedir. Spondiloartropati (SpA) ortak patofizyolojik, klinik, radyolojik ve genetik özelliklere sahip olan kronik romatizmal hastalıklar ailesine verilen isimdir. HLA-B27 antijeni ile güçlü ilişki içerisinde olduğu gösterilmiş olan spondiloartropatiler, aksiyal ve entezeal inflamasyonun baskın olduğu, yeni kemik formasyonu ile seyretmektedir. Spondiloartropatiler sıklıkla 45 yaş altı başlayan inflamatuar bel ağrisı ile karakterize hasta grubunu oluşturmaktadır. İskelet tutulumu yanında anterior üveit, psöriyazis, inflamatuar bağırsak hastalığı ile ilişkili enteropatik artritler ve reaktif artritler gibi iskelet dışı tutulumlarla karakterize, heterojen bir hastalık grubudur ${ }^{1}$. Ankilozan spondilit (AS) ise spondiloartropati grubu hastalıkların prototipi olarak bilinen ve etiyolojisi tam bilinmeyen, sakroiliit ve spondilite bağlı inflamatuar bel ağrısı, ankiloza yol açan sindesmofitlerin oluşumu ve siklıkla periferik artrit, entezit ve akut anterior üveitle birlikte olan kronik inflamatuar bir hastalıktır². İnflamatuar bel ağrısı spondiloartropatilerin en belirgin klinik özelliğidir; İnflamatuar bel ağrısının tanımı Avrupa Spondiloartropati Çalışma Grubu (European Spondyloarthropathy Study Group-ESSG) ${ }^{3}$, Assessment of Spondyloarthritis İnternational Society (ASAS) ${ }^{4}$, Callin $^{4}$, ve Berlin ${ }^{5}$, Amor $^{6}$ gibi çeşitli gruplar tarafından yapılmıştır. ESSG ve 
Amor kriterleri; MRI görüntüleme yöntemleri yaygın olmadığı zamanlarda daha çok kullanılmıştır.

Ankilozan spondilit için ise Roma Kriterleri, Modifiye Newyork Kriterleri ve ESSG SpA sınıflandırma kriterleri kullanılmıştır. En son 2013 de ASAS grubu tarafindan spondiloartropatiler çatısı altında ve AS yi de içine alan daha geniş sınıflandırma kriterleri düzenlenmiştir. $^{7}$ ASAS Aksiyel (axSpA) sinıflandırma kriterlerinin iki kolu vardır. Görüntüleme kolu ve klinik kolu; bu kriteler sadece inflamatuvar bel ağrısı (3ay > uzun süren ağrı + yaş <45 olması) varlığında geçerlidir. Görüntüleme kolunda konvansiyonel radyografide sakroiliit görülen olgular veya MRI da kemik iliği ödemi görülen olgularda ilave bir SpA klinik bulgusu varsa olgu aksiyel SpA olarak değerlendirilmektedir. HLA-B 27 pozitif hastalarda ise en az iki SpA bulgusu varsa aksiyel SpA olarak değerlendirilebilir. ${ }^{7}$ İnflamatuvar bel ağrısı olmayan ancak periferal artrit, entezit veya daktilit olan hastalarda periferal SpA olarak değerlendirilmektedir. Bu iki set birlikte ASAS SpA kriterlerini oluşturmaktadır. 2006 da psoriatik artrit için CASPAR (ClASsification criteria for Psoriatic ARthritis) kriterleri geliştirilmiştir. $^{8}$

Spondiloartropati grubu hastalarda tanida yönlendirici başlıca klinik bulguyu inflamatuar bel ağrısı oluşturmaktadır. Çeşitli çalışma gruplarına göre farklı inflamatuar bel ağrısı tanımlamaları yapılmıştır. ASAS'a göre inflamatuar bel ağrısı 40 yaş altı başlayan, sinsi seyirli, egzersizle düzelen, istirahatle düzelmeyen ve gece ağrısı olması şeklindeki 5 klinik bulgudan 4'ünün bulunması olarak tanımlanmıștır. ${ }^{4}$ Callin kriterlerine göre; 40 yaș altı başlangıç, bel ağrısının 3 aydan uzun sürmesi, sinsi başlangıçlı olması, sabah sertliği varlığı ve egzersizle bel ağrısının düzelmesi olan 5 kriterden yine 4'ünün bulunması inflamatuar bel ağrısı olarak tanımlanmıştır. ${ }^{4}$ Berlin Kriterlerine göre inflamatuar bel ağrısı ise 4 kriterden 2'sinin olması ile tanımlanmıștır. Bu kriterler sabah tutukluğunun 30 dakikadan uzun sürmesi, gecenin ikinci yarısında ağrı ile uyanma, gezici gluteal ağrı, egzersizle ağrılarda azalma olarak tanımlanmıștır. ${ }^{5}$ Psöriatik artrit sinıflamasında kullanılan CASPAR kriterlerine göre psöriatik artrit tanımlaması inflamatuar artiküler, entezeal veya spinal ağrı ile birlikte belirtilen kriterlerde verilen puanlamalara göre 3 ve üzeri puan alan hastalar psöriatik artrit olarak sınıflanabilir denmiştir. Bu kriterlerde yapılan puanlamalar şu şekildedir: Psöriasis kanıtı olması (mevcut psöriasis 2 puan, hastanın tanımladığı psöriasis öyküsü 1 puan, ailede psöriasis öyküsü 1 puan), psöriatik tırnak distrofisi ( onikoliz veya pitting veya hiperkeratozis 1 puan), negatif romatoid faktör olması 1 puan, daktilit veya daktilit öyküsü 1 puan, radyolojik olarak jukstaartiküler yeni kemik oluşumunun varlığ 1 puan olarak tanımlanmıştır. $^{7}$ ESSG spondiloartropati sınıflandırma kriterlerine göre inflamatuar spinal 
ağrı veya sinovit (asimetrik ve özellikle alt ekstremitelerde) ile beraber 7 kriterden bir veya daha fazlasını içermesi ile SpA grubu hastalıklar sınıflandırılabilir denmiştir. $\mathrm{Bu} 7$ kriter ailede benzer hastalık öyküsü, psöriasis, inflamatuar barsak hastalığg, üretrit, servisit veya artritten 1 ay önce akut diyare, gluteal bölgede ağrı, entezopati, sakroiliit olarak tanımlanmıştır. ${ }^{9}$

ASAS tarafindan yapılan güncel siniflama kriterlerinde şunlar göz önüne alınmıştır; Klinikte fiziyatristler ve romatologlar SpA hastasını primer tutulumunun aksiyel ve periferal tutulumlu olmasına göre sinıflamaktadırlar. $\mathrm{Bu}$ ayırımı daha gerçekçi yapabilen yeni ASAS kriterlerine göre hastalar başlıca yakınmasına göre aksiyel Spondiloartropati (axSpA) veya başlıca yakınmasının periferde başlamasına göre periferal spondiloartropati (pSpA) olarak değerlendirilmektedir. ${ }^{10}$

Olgumuzda ise inflamatuar aksiyal ağrı hastalık başlangıcından itibaren 2 y1l süresince sadece boyun bölgesinde sınırlı kalmıştır. Hasta ASAS, Callin, Berlin, Roma, Modifiye New York çalışma grupları tarafından yapılmış tanımlamalarla inflamatuar bel ağrısı (inflammatory back pain) grubuna sokulamamaktadır. Ancak bu olgudaki aksiyal boyun ve sırt ağrısı ESSG çalışma grubunun inflamatuar spinal ağrı tanımlamasına uymaktadır. $\mathrm{Bu}$ tanımlamaya dayanarak çekilen sakroiliak grafisi normal fakat sakroiliak MRI da sakroiliit gözlenmiştir. Bu gerekçeyle ve MRI bulgusuyla non-radyografik axSpA tanısı konulmuştur. ESSG kriterlerinde ise inflamatuar ağrı spinal ağrı olarak tanımlandığı için hastamız inflamatuar ağrı ve $\quad \mathrm{SpA}$ olarak değerlendirilebilmiştir. Hasta inflamatuar bel ağrısı tanımlamadığı için 2 yıl boyunca servikal ağrı gerekçesiyle miyofasiyal ağrı sendromu olarak değerlendirilmiştir. Oysa erken tanıda katkısı olur gerekçesiyle kronik özellikler gösteren boyun ağrısı olgularının da SpA olabileceği düşünülerek sakroiliak grafi ve MR istenebileceğini öngörmekteyiz. Şu ana kadar yapılmış inflamatuar bel ağrısı tanımları güncellenerek aksiyal spinal ağrı şeklinde yeni düzenleme yapılabilir. Çünkü ASAS, Callin, Berlin, Roma kriterlerinde ağrının lokalizasyonu "back pain" yani bel ve dorsal ağrı olarak tanımlanmıştır. Diğer bir açıdan değerlendirirsek; HLA-B27 negatif olan ve boyun ağrısı ile 2 y1l boyunca takip ettiğimiz bu hastamıza daha erken dönemde inflamatuar spinal ağrı tanımlaması yapsaydık daha erken dönemde non-radyolografik axSpA olabileceğini öngörerek atipik inflamatuar spinal ağrı tanımlamasını yapabilir ve SpA grubuna koyabilecektik. Veya klinik bulguları atipik olduğu için atipik non-radyolojik SpA şeklinde yeni bir klinik tanımlama olsaydı bunu yapabilirdik.

Özellikle erkek olgularda aksiyel tutulumun yukarıdan aşağıya bir patern de görülebileceğini öngören ampirik veriler de vardır. Klasik bilgilere göre servikal tutulumun özellikle kadınlarda ve hastalık süresi uzun olan hastalarda 
daha s1k görüldüğü bilinmektedir. ${ }^{11} \mathrm{Bu}$ gerekçe ile inflamatuar karakterde özellik taşıyan servikal ağrılı hastalarda erken dönemde inflamatuar bel ağrısı akla getirilerek ilgili incelemelerin yapılmasında fayda olduğunu öngörmekteyiz.

\section{KAYNAKLAR}

1. Kiltz U, Heijde D Van Der, Boonen A, Braun J, Braun J. The ASAS Health Index (ASAS HI) - a new tool to assess the health status of patients with spondyloarthritis. Clin Exp Rheumatol. 2014 Sep-Oct;32(5 Suppl 85):S105-8. Epub 2014 Oct 30. :105-108.

2. Braun J, Sleper J, Ankylosing spondylitis. Lancet, 2007;369:1379-90.

\section{Rudwaleit M, Metter A, Listing J, Sieper} J, Braun J. Inflammatory back pain in ankylosing spondylitis: a reassessment of the clinical history for application as classification and diagnostic criteria. Arthritis Rheum, 2006; 54: 569-78.

4. Sieper J, Rudwaleit M, Baraliakos X, et al. The Assessment of SpondyloArthritis international Society (ASAS) handbook: a guide to assess spondyloarthritis. Ann. Rheum. Dis., 2009;68 Suppl 2(May):ii1-44. doi:10.1136/ard.2008.104018.

5. Calin A, Porta J, Fries JF, Schurman DJ. Clinical history as a screening test for ankylosing spondylitis. JAMA, 1977;237:2613-4.

6. Lipton S, Deodhar A. The new ASAS classification criteria for axial and peripheral spondyloarthritis: promises and pitfalls, Systemic Review, Division of Arthritis \& Rheumatic Diseases, Oregon Health \& Science University, Mail Code OP-09, 3181 SW Sam Jackson Park Road, Portland, OR 97239, 2012, USA.

7. Bakker P, Moltó A, Etcheto A, Van den Bosch F, Landewé R, Van Gaalen F, Dougados M, Van der Heijde D. The performance of different classification criteria sets for spondyloarthritis in the worldwide ASASCOMOSPA study. Arthritis Research \& Therapy, 2017; 19:96 DOI 10.1186/s13075017-1281-5.

8. Taylor W, Gladman D, Helliwell P, Marchesoni A, Mease P, Mielants $\mathrm{H}$. CASPAR Study Group. Classification criteria for psoriatic arthritis: development of new criteria from a large international study. Arthritis Rheum., 2006;54:2665-73.

9. Şendur FÖ. Spondiloartropatilerin Temel Özellikleri ve Ayırıcı Tanı ve Tedavisinin Genel Kriterleri- Derleme ADÜ Tıp Fakültesi Dergisi 2001; 2(2) : $31-35$.

10. Rudwaleit M, Van der Heijde D, Landewé R, Akkoc N, Brandt J, Chou CT, et al. The Assessment of Spondyloarthritis International Society classification criteria for peripheral spondyloarthritis and for spondyloarthritis in general. Ann Rheum Dis. 2011;70:25-31.

11. El Maghraoui A, Bensabbah R, Bahiri R, Bezza A, Guedira N, Hajjaj-Hassouni N. Cervical spine involvement in ankylosing 
spondylitis Clin Rheumatol, 2003; 22: 94-98

DOI 10.1007/s10067-002-0681-2. 


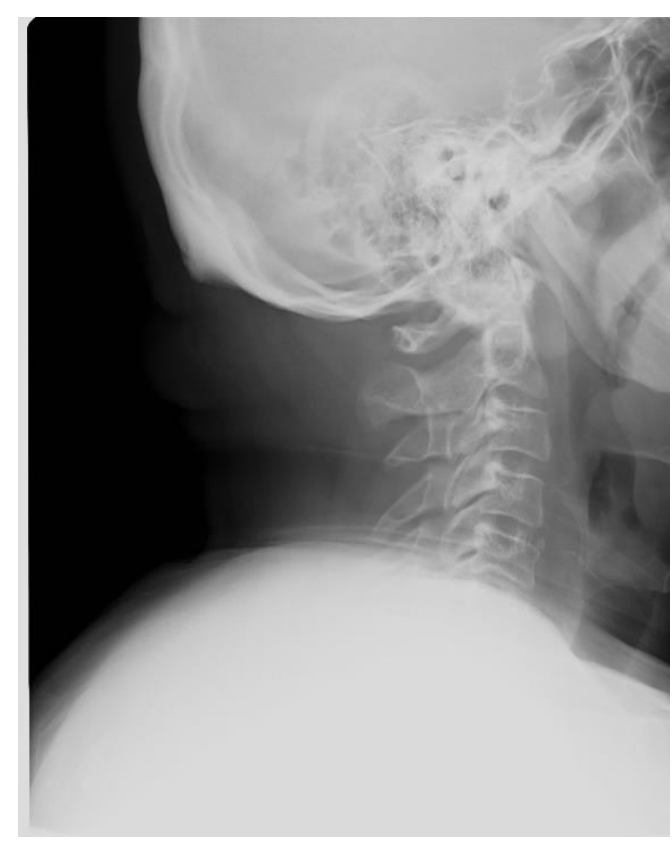

Resim 1. Servikal lateral grafi

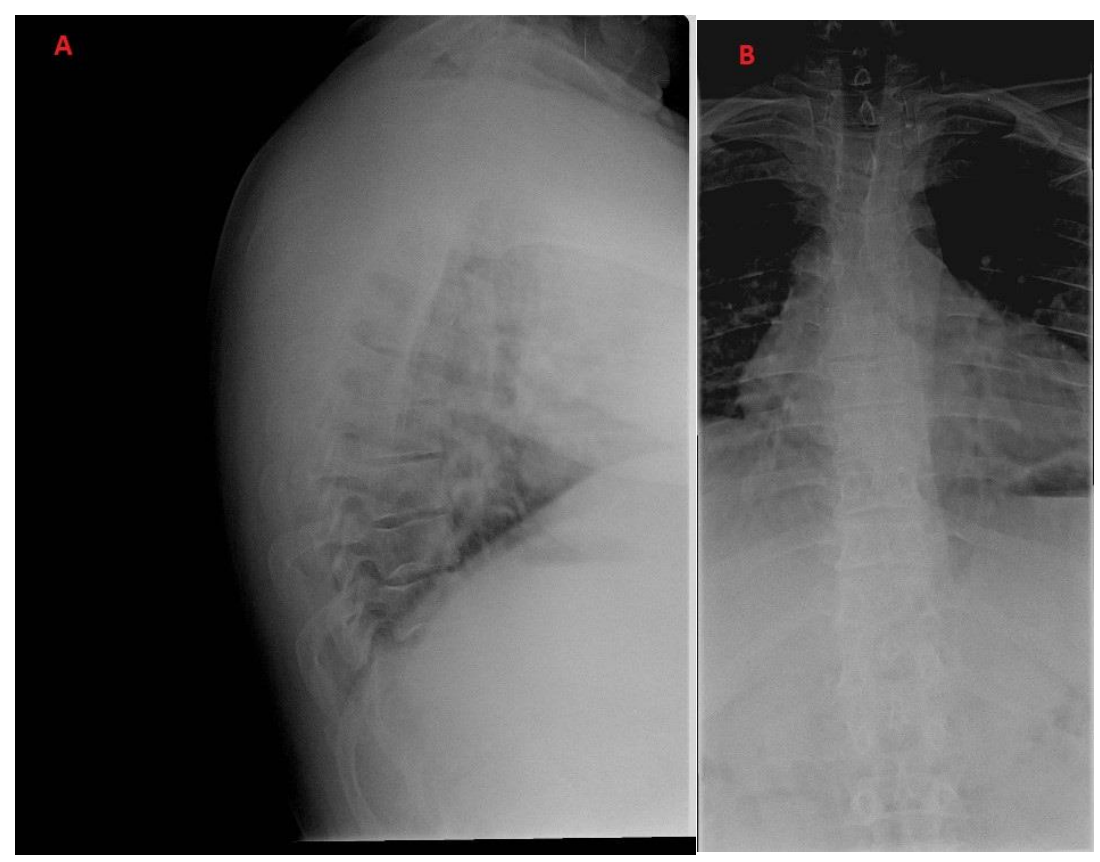

Resim 2. Dorsal lateral (A) ve AP (B) grafiler. 


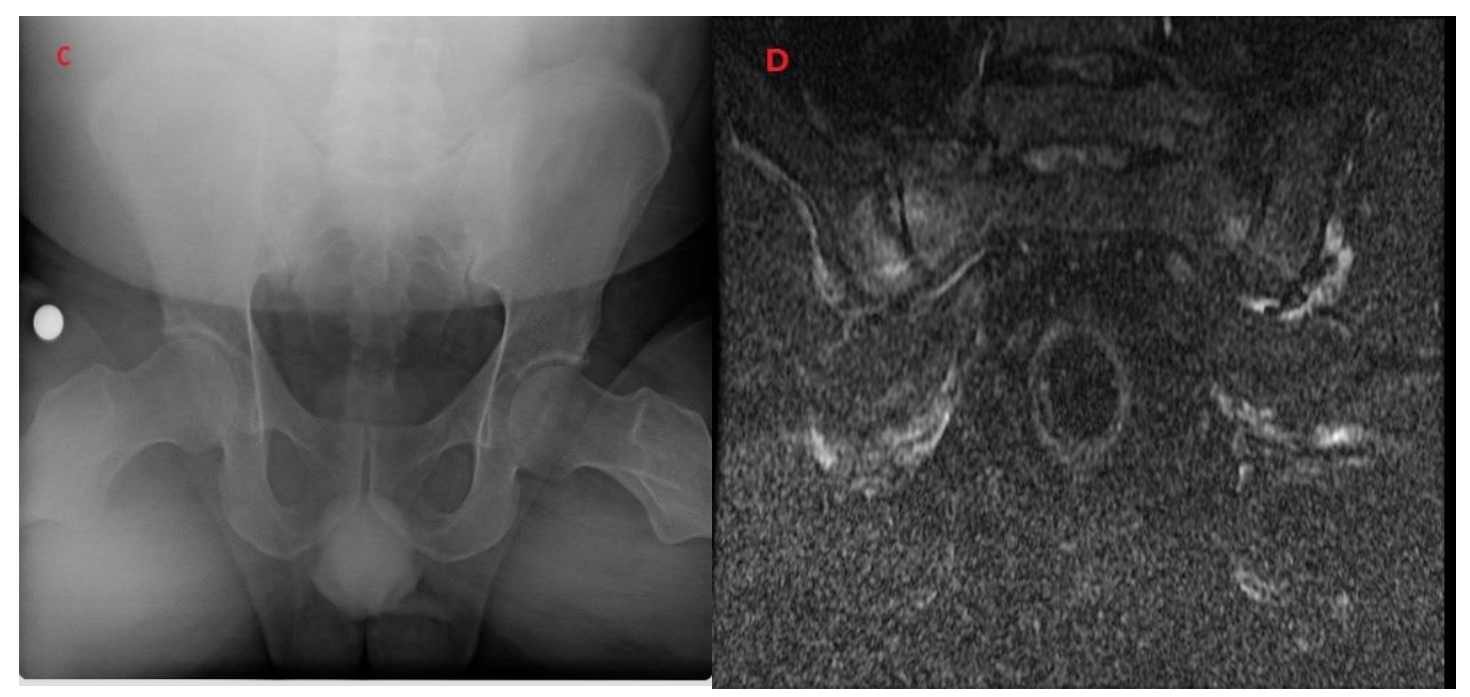

Resim 3. Suprapubik pozisyonda sakroiliak grafi (C) ve MRI (D) görüntüleri 